\title{
Imaging features of idiopathic granulomatous mastitis - Case report
}

luciana Graziano $^{1}$, Almir Galvão Vieira Bitencourt ${ }^{2 *}$, Caroline Baptista da Silva ${ }^{3}$, Camila Souza Guatelil ${ }^{1}$, Juliana Alves Souza ${ }^{1}$, Miriam Rosalina Brites Poli ${ }^{1}$, Elvira Ferreira Marques ${ }^{1}$

${ }^{1} \mathrm{MD}$ - Physician, Member of the Department of Imaging, A.C. Camargo Cancer Center, São Paulo, SP, Brazil

${ }^{2} \mathrm{PhD}$ - Physician, Member of the Department of Imaging, A.C. Camargo Cancer Center, São Paulo, SP, Braz

${ }^{3} \mathrm{MD}$ - Resident Physician of the Department of Imaging. A.C. Camargo Cancer Center, São Paulo, SP, Brazil

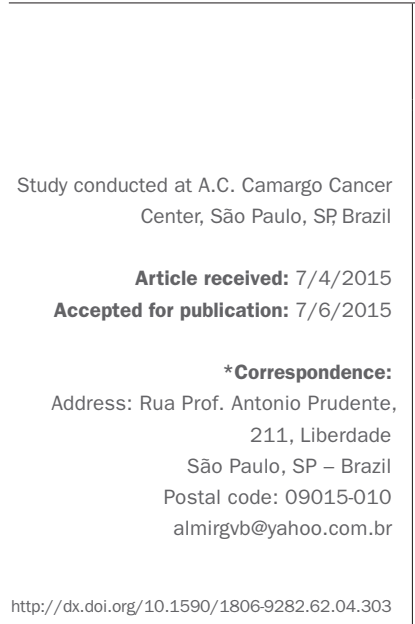

\section{SUMmARY}

Idiopathic granulomatous mastitis is a rare disorder of unknown etiology. This disease occurs mostly in young women and often after the lactation period. Women usually present with a fixed, painful mass, sparing the retroareolar region, associated with skin thickening and possible ulceration that mimics carcinoma. Nipple discharge can be present and bilateral involvement may occur in up to $25 \%$ of cases. In this case report, we present a typical case of histologically confirmed idiopathic granulomatous mastitis, highlighting the imaging findings, including magnetic resonance imaging (MRI), which may favor this diagnosis and enable better clinical management of these patients.

Keywords: breast, mastitis, granulomatous mastitis, magnetic resonance imaging.

\section{INTRODUCTION}

Idiopathic granulomatous mastitis, also known as granulomatous lobular mastitis, is a rare disease of unknown etiology. This disease was first described by Kessler and Wollocb in 1972, and its diagnosis is made by ruling out other known causes of granulomatous disease. It occurs mostly in young women and often after the lactation period. ${ }^{1-3}$

The primary cause of the disease is speculated to be an injury to the ductal epithelium, leading to extravasation of glandular secretions into the lobe tissue, creating inflammatory lesions. An autoimmune process has been suggested in patients after pregnancy, with the disease generally occurring within 6 years after pregnancy. ${ }^{1,3}$

Clinically, these women present with a hardened, fixed and painful mass, sparing the retroareolar region, with $0.5 \mathrm{~cm}$ to $15 \mathrm{~cm}$ in size, associated with skin thickening and possible ulceration that mimics carcinoma. Nipple discharge can be present and bilateral involvement may occur in up to $25 \%$ of cases. Secondary axillary lymphadenopathy may occur in up to $40-60 \%$ of cases. $^{4,5}$

The aim of this study is to report a case of idiopathic granulomatous mastitis, highlighting the image aspects, especially magnetic resonance imaging (MRI), and conduct a literature review.

\section{Case report}

Female patient, 38 years old, G2P2A0, last delivery two years earlier, admitted to an oncological reference center with complaints of pain and volume increase of the left breast for 30 days associated with fever. She reported use of hot compresses, anti-inflammatory drugs and oral antibiotics without clinical improvement. She reported having thalassemia minor. She denies any family history of breast or ovary cancer. On physical examination, the breasts showed areas of asymmetric bulging with areas that were hardened, mobile and painful on palpation, and discreet erythema on the skin in the upper-lateral quadrant of the left breast.

Mammogram revealed heterogeneously dense breasts and focal asymmetry in upper-outer quadrant of the left breast (Figure 1). Ultrasonography revealed heterogeneous, predominantly hypoechoic areas, with indistinct margins and increased echogenicity of the adjacent tissues in the upper-outer quadrant of the left breast, with internal vascularization on color Doppler (Figure 2). Axillary and intramammary lymph nodes were found, with unusual appearance, rounded and hypoechoic with preserved dimensions and reactive appearance.

Breast MRI showed, on the left, an area of non-masslike enhancement, heterogeneous and poorly defined, occupying the lateral quadrants, with low signal inten- 
FIGURE 1 Mammogram revealing heterogeneously dense breasts, with focal asymmetry in the upper-lateral quadrant of the left breast (highlighted).
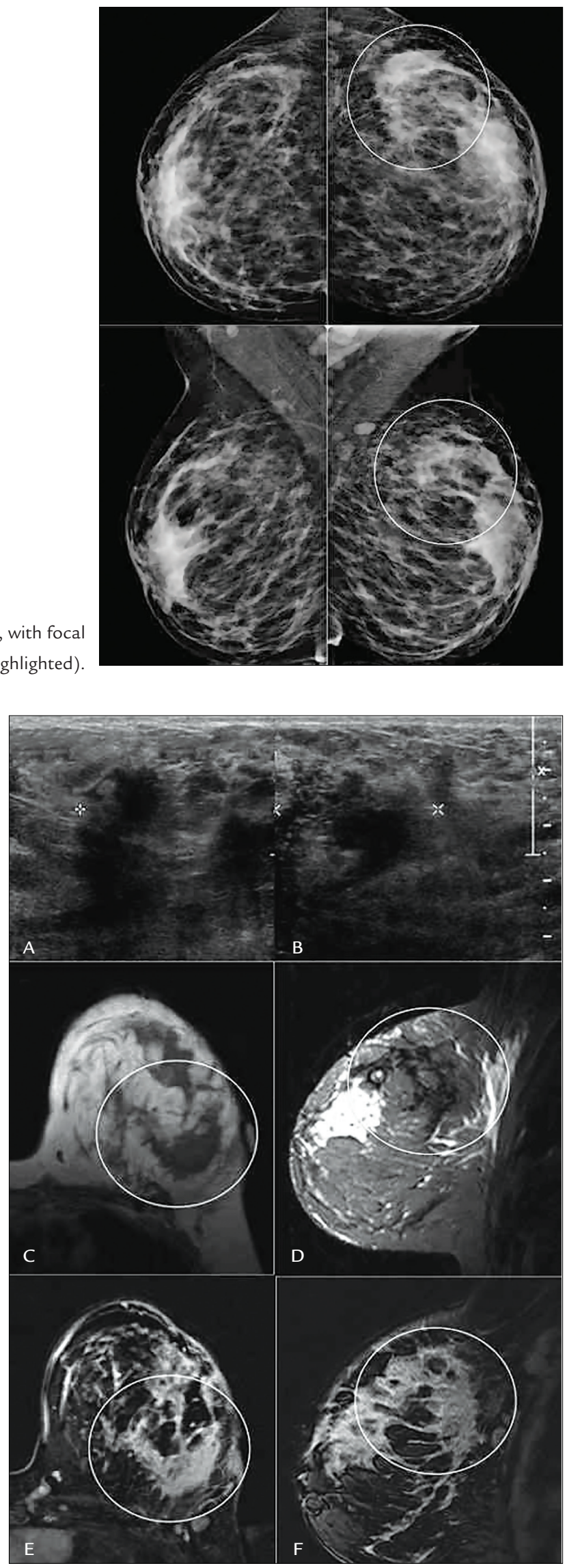

FIGURE 2 Ultrasonography showing a heterogeneous, predominantly hypoechoic area, with indistinct margins, in the upper-outer quadrant of the left breast ( $A$ and $B$ ). MRI showing an area of non-mass enhancement with regional distribution occupying the lateral quadrants of the left breast (highlighted), with low signal intensity on axial T1 (C) and sagittal T2 (D) scans, presenting an heterogeneous internal enhancement pattern ( $E$ - axial; $F$ - sagittal). 
sity on T1 and T2 (Figure 2). MRI also revealed a mass enhancement at the upper quadrants of the right breast, which was subsequently identified in targeted ultrasound (Figure 3).

The patient underwent ultrasound-guided percutaneous core needle biopsy on both breasts, which showed marked chronic inflammation associated with granulomas and microabscesses in breast lobules, more evident to the left. No evidence of malignancy was found. Search for etiological agents using Grocott, PAS and Ziehl-Neelsen special staining yielded negative results. Thus, the final pathological diagnosis was idiopathic granulomatous mastitis.

\section{Discussion}

The case described above is typical of idiopathic granulomatous mastitis in a patient with recent pregnancy history, who showed prolonged symptoms of a palpable mass in the breast associated with inflammatory signs, and no improvement after treatment with antibiotics. This diagnostic possibility should always be remembered in such cases because the clinical and imaging findings can mimic malignancy. Bilateral involvement is unusual and may be associated with increased risk of recurrence and resistance to medical treatment. ${ }^{6}$

The most common mammographic finding is focal asymmetry, not associated with distortions or microcalcifications; nodules with defined margins are less common. Sonographic findings include one or more irregular hypoechoic masses associated with increased echogenicity of the parenchyma without posterior acoustic shadowing. Doppler study showed an increase of vascularization. These imaging findings are nonspecific and mimic breast carcinoma. ${ }^{1,2,4}$

These findings on MRI are little known because there are few reports in the literature. The most common is a non-mass enhancement with the following distribution: segmental, ductal and regional. The most common mass findings are irregular margins with intense post-contrast peripheral enhancement. The kinetic curve is usually suspicious. However, the morphological findings of lesions often do not distinguish them from malignant lesions. ${ }^{7}$ In the case above, MRI showed involvement of the contralateral breast that had not initially been identified on conventional tests.

As described above, diagnostic confirmation can be done by percutaneous core needle biopsy, which is more accurate than fine-needle aspiration. ${ }^{2,5}$ Microscopic analysis showed mixed inflammatory cell infiltrate (mononuclear and polymorphonuclear), abundant with histiocytes within and outside of the breast lobules, non-caseating granulomas and microabscesses (neutrophil cluster), and absence of infectious etiologic agents. ${ }^{2,3}$

Prognosis and treatment depend on the disease presentation. Steroid therapy is indicated for extensive cases, but not for localized forms. Surgical removal is indicated in refractory cases, but may be associated with the occurrence of fistulas and scars. Recurrence decreases when the surgical margins are not compromised. The course of the disease is usually long with a significant impact on quality of life. Prognosis is good; however, sometimes there is delay in the improvement of the disease, and possible recurrences and interventions can leave sequelae. ${ }^{1,2,8}$ Therefore, knowing this pathological entity, its clinical course and imaging findings is important for proper medical management, since this is a benign entity.

\section{Resumo}

Aspectos de imagem na mastite granulomatosa idiopática - Relato de caso

A mastite granulomatosa idiopática é uma afecção rara e de etiologia desconhecida. Essa doença ocorre principal-

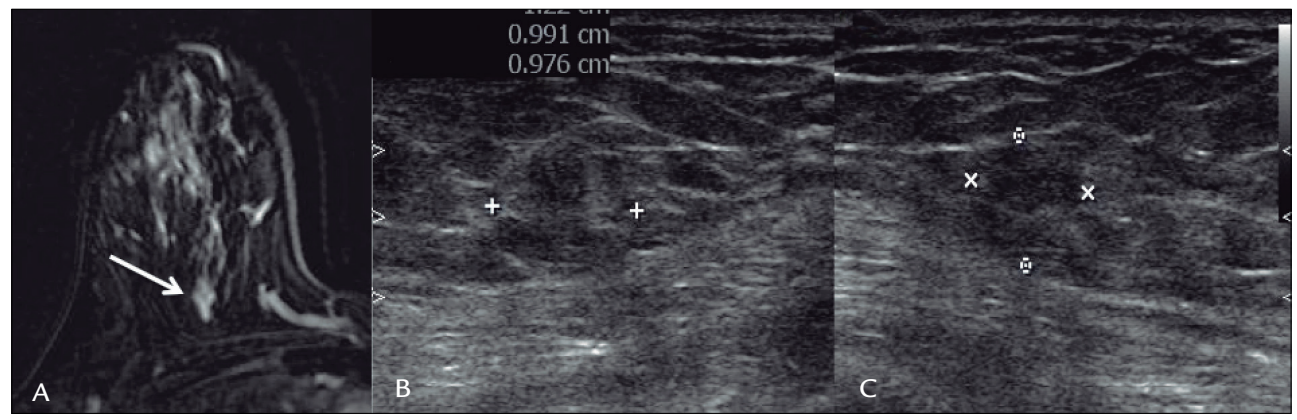

FIGURE 3 MRI (A) showing a mass enhancement at the upper quadrants of the right breast (arrow). Targeted ultrasound (B) revealing a heterogeneous isoechoic mass in the same topographic of the MRI finding. 
mente em mulheres jovens e frequentemente após o período de lactação. As mulheres apresentam clinicamente massa endurecida, fixa, dolorosa, poupando a região retroareolar, associada a espessamento cutâneo, podendo ulcerar, simulando carcinoma. Descarga papilar pode estar presente e o envolvimento bilateral pode ocorrer em até $25 \%$ dos casos. Neste relato, apresentamos um caso típico de mastite granulomatosa idiopática, com confirmação histológica, destacando os aspectos de imagem, incluindo a ressonância magnética (RM), que possam favorecer o diagnóstico e possibilitar um melhor manejo clínico dessas pacientes.

Palavras-chave: mama, mastite, mastite granulomatosa, imagem por ressonância magnética.

\section{References}

1. Gautier N, Lalonde L, Tran-Thanh D, El Khoury M, David J, Labelle M, et al. Chronic granulomatous mastitis: imaging, pathology and management. Eur J Radiol. 2013; 82(4):e165-75.

2. Larsen LJH, Peyvandi B, Klipfel N, Grant E, Iyengar G. Granulomatous lobular mastitis: imaging, diagnosis, and treatment. Am J Roentgenol. 2009; 193(2):574-81.

3. Ocal K, Dag A, Turkmenoglu O, Kara T, Seyit H, Konca K. Granulomatous mastitis: clinical, pathological features, and management. Breast J. 2010; 16(2):176-82.

4. Cheng L, Reddy V, Solmos G, Watkins L, Cimbaluk D, Bitterman P, et al. Mastitis, a radiographic, clinical, and histopathologic review. Breast J. 2015; 21(4):403-9.

5. Aghajanzadeh M, Hassanzadeh R, Alizadeh Sefat S, Alavi A, Hemmati H, Esmaeili Delshad MS, et al. Granulomatous mastitis: presentations, diagnosis, treatment and outcome in 206 patients from the north of Iran. Breast. 2015; 24(4):456-60.

6. Velidedeoglu M, Kilic F, Mete B, Yemisen M, Celik V, Gazioglu E, et al. Bilateral idiopathic granulomatous mastitis. Asian J Surg. 2016; 39(1):12-20.

7. Yildiz S, Aralasmak A, Kadioglu H, Toprak H, Yetis H, Gucin Z, et al. Radiologic findings of idiopathic granulomatous mastitis. Med Ultrason. 2015; 17(1):39-44.

8. Kiyak G, Dumlu E, Kilinc I, Tokaç M, Akbaba S, Gurer A, et al. Management of idiopathic granulomatous mastitis: dilemmas in diagnosis and treatment. BMC Surg. 2014; 14(1):66. 